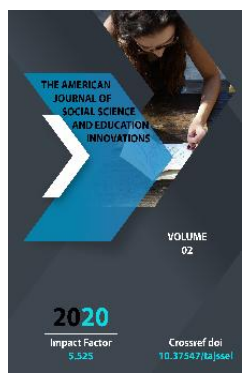

\title{
The Importance Of Military Traditions In Improving The Professional Training Of Military Servants
}

\author{
Abidjanova Mukhlisa Abdukakharovna \\ Teacher Of The Cycle Of Pedagogy And Psychology Of The Department Of Humanities, \\ Academy Of The Armed Forces Of The Republic Of Uzbekistan, Tashkent, Uzbekistan
}

Journal Website:

http://usajournalshub.c

om/index,php/tajssei

Copyright: Original

content from this work

may be used under the

terms of the creative

commons attributes

4.0 licence.

\section{ABSTRACT}

The army, as a social institution, plays an important role in ensuring the stability of society and maintaining peace. At the same time, it is important to study the genesis of the formation of military traditions, their further development and improvement. After all, the Armed Forces is manifested as a specific society, where there are specific military traditions that have been formed over a certain historical period of time. It is the military traditions that have a positive impact on the combat readiness of servicemen serving in the armed forces, as well as serve to increase their combat readiness. This article highlights the role of military and combat traditions, which have been formed and developed over the centuries in our national army, in increasing the combat readiness and combat readiness of troops as a phenomenon of military traditions.

\section{KEYWORDS}

Tradition, military traditions, military values, mobile traditions, martial traditions.

\section{INTRODUCTION}

No one wants to remember the misfortunes they have experienced throughout their lives, the days of anxiety and oppression. But the days of pleasure, in order to appreciate the exemplary life, one must sometimes look to the past. This, in turn, motivates a person to re-evaluate his attitude towards himself and those around him, the processes that take place, items and objects. As a result, there is a sorting mechanism in its information activity 
that distinguishes white from black, sin from good, good from evil, peace from war, and stability from instability. [8.50-55, 2.98-108] Given the fact that this, in turn, requires the study of the positive traditions inherent in the military and the study of its important aspects, it is significance to analyze the scientific research in this area. [5.195-197, 7.200-242, $10.150,15.96$ ]

After all, the use of combat traditions in the training of military personnel, the study of ideals and values inherited from history, passed down from generation to generation, is important in improving the modern army. Strengthening spiritual and political unity is the most important need for the army and society. This unity supports and represents military traditions.

The role of military and combat traditions, which have been formed and developed over the centuries in our national army, is invaluable in the training of highly professional and combat-ready servicemen, combat and mobilization readiness of the army.

\section{MATERIALS AND METHODS}

Certain aspects of military traditions as the object of research in such fields as history, philosophy, pedagogy, psychology have been studied, and their role in the management of military communities can be seen in the research work of foreign scholars A.A. Zubkova, M.N. Kokoeva, A.M.Kuznetsova, Pashkova, O.I. Torkunova and O.V. Shevchenko. [17. 154-157].

In our country, the historical, philosophical, pedagogical, political, economic and military aspects of this topic have been studied by researchers such as S.Ahrorov [3.22-24], J.Ramatov [11.17-20], Z.Alimardonov [1.197],
R.Samarov [16.226-229], Sh.Paxrutdinov [9.1112], R.Rashidov [14.47], A.Raxmonov [12., 13.6], A.Nazarov [6.45].

However, issues related to military tradition and values have not been studied as a separate research topic.

The word tradition [18.89] is derived from the Arabic 'ن ان - meaning a rule and custom passed down from generation to generation. The National Encyclopedia of Uzbekistan states, "Tradition is a material and spiritual value inherited from the past to the future, passed down from generation to generation, reflected in various spheres of society. There are national, cultural, domestic, socio-political, religious and other traditions. Traditions are formed in the process of historical development of nations. People's lifestyles and material conditions influence the formation of different traditions. Certain social rules, morals, customs, rituals, etc. are manifested as traditions. Traditions are: a) a socio-historical phenomenon; b) an integral part of the processes of public life; c) criteria for determining the lives and activities of people; g) can be described as one of the spiritual factors governing society and people" [19.375].

Among the most important combat traditions of the Armed Forces are:

- Loyalty to the motherland, constant readiness to defend it, self-confidence;

- Commitment to the military oath;

- Military duty, mass heroism in battle;

- Combat friendship;

- Striving to acquire military professional knowledge, improve military skills;

- Striving for high vigilance, constant maintenance of combat readiness of units. Traditions are determined by their presence in all spheres - material, political, artistic, moral, 
military, everyday, physical culture. There are strict traditions that do not allow for innovation and deviations in behavior. They are characterized by a very long lifespan, passing from generation to generation without change. Another type is flexible, mobile traditions. They have a very wide range of variability and diversity, but the foundations of tradition also remain unchanged. In this case, traditions can develop with new norms, rules, which will change depending on the situation. Traditions form the "collective memory" of societies and social groups, ensuring their continuity in development. It is also possible to see the role of traditions with their own characteristics in individual groups, classes, strata. Each generation has at its disposal a set of examples of certain traditions, which not only study them, but always make their own interpretation and choice. In this sense, each generation chooses not only its own future, but also its past.

The organization of military activity, the formation of military-professional culture in the process of training professionals, the skillful use of military traditions will improve the morale of communities, instill in the members of the unit love for their profession, increase their efficiency, prevent the formation of various negative traditions. [4.2]. This is of practical importance for the implementation of pedagogical-psychological prevention of personnel.

The combat traditions of the Armed Forces have historically been established in military service, passed down from generation to generation, and are reflected in the rules and regulations of military service. Many countries of the world have their own fighting traditions, the composition of which is formed in each country taking into account its historical features. Combat traditions are determined by social and state structure, as well as national characteristics and the functions of the Armed Forces.

Each line of military service has its own traditions, such as intelligence officers, border guards, pilots, and so on. As a rule, these traditions are associated with the history of a particular team of the Armed Forces, its professional characteristics, heroism and other events. But there are many common traditions for all Armed Forces.

In modern warfare and conflict, it is important to use combat traditions in the training of personnel. There are objective and subjective reasons for this. All battles and wars in history, especially in the First World War, serve as an example of the courage and patriotism of all peoples, and serve to pass on the traditions of war to young people serving in the modern Armed Forces. But it all goes down in history. It would be good if examples of new heroism, such as the First World War, the historical transmission of examples in the spirit of patriotism, such as heroism, patriotism and courageous actions committed by contemporaries, were applied to military traditions.

Thus, military traditions are the observance of the rules of etiquette and discipline of servicemen, which are historically formed in the military and passed down from generation to generation, associated with the exemplary performance of military service.

Martial traditions are formed in the process of fighting. Their purpose is to apply moral education in maintaining the high moral and combat qualities of servicemen, and for combat conditions (transfer of advanced experience, mutual assistance in battle and 
training, protection of the national flag, solidarity with the commander in battle).

\section{RESULTS}

As for the military and combat traditions of the Armed Forces of Uzbekistan, they include:

- Demonstration of mass heroism and courage in difficult times for the country;

- Introduction of combat experience in the educational process;

- fidelity to the military oath;

- Demonstration of zeal and dedication to victory;

- Respect for the commander and protect him in battle;

- Hatred of cowards and traitors;

- To prefer to die in battle, to be captured;

- To pay military respect to those killed in battle;

- High sensitivity and honesty;

- care for the health and lives of subordinates;

- Strict adherence to the requirements of the military oath and general military regulations;

- Not to allow simplification and facilitation in military exercises;

- Protection of military and state secrets;

- Be able to accurately assess the militarypolitical situation;

- Military brotherhood and military friendship, mutual assistance;

- Humane treatment of the defeated enemy, the captives;

- Knowledge of martial arts traditions, their preservation and enrichment;

- Demonstration of patriotism and devotion in battle;

- Proud to serve in the Armed Forces.

\section{CONCLUSION}

In conclusion, it can be said that the military and combat traditions existing in our national army play an important role in raising the combat readiness and readiness of the troops, the professional level of servicemen. Therefore, commanders are required to know the military and combat traditions, to use them effectively in the training of personnel. Today, one of the important aspects of strengthening the defense capabilities of our country is that the serviceman has a respect for military and combat traditions, adheres to them and, of course, enriches them.

\section{REFERENCES}

1. Alimardonov Z.Sh. Improving the professional competence of future officers in higher military education institutions // Dissertation for the degree of Doctor of Philosophy (RhD) in Pedagogical Sciences. - Tashkent, 2019. № 2. - $197 \mathrm{p}$.

2. Aronov P.A. The origin of knowledge: origins and foundations // Problems of Philosophy. 2008. - No. 4. - P.98-108.

3. Axrorov S. Deviation of military behavior //. Protection +, 2008, issue 2. -P.22-24.

4. Ahrorov S.Yu. Social features of deviant behavior in the personality of servicemen /l Candidate of Sociological Sciences dissertation. - Tashkent: UzMU, 2009. - P. 2.

5. Meshcheryakov V.P. Brain mechanisms of information activity: systems of consciousness and unconscious processes in cognition and intuition // Informatization and problems of humanitarian education. - Krasnodar, 1995. - P. 195-197.

6. Nazarov A.N. Evolution of security and stability of political development in the 
context of globalization // Abstract of the dissertation for the degree of Doctor of Philosophy (PhD) in Political Science. - T., 2018. - 45 p.

7. Nepomnyashikh V.A. Models of Autonomous Search Behavior // From Behavior Models to Artificial Intelligence / Ed. V.G. Redko. - M.: Publishing house URSS, ser. "Science of the artificial", 2006. - P. 200-242.

8. Nikitina E.A. Unity of consciousness: communicative and informational approaches // Scientific Bulletin of MSTU GA, No. 113 (3), series History, philosophy, sociology. - Moscow, 2007. - P. 50-55.

9. Paxrutdinov Sh. Threat is a destructive force (collection of articles and reports). T.: Akademiya, 2001. - P.11-12.

10. Penkin S.A. Philosophical analysis of the quantum concept of consciousness // Dis. ... Cand. Philos. sciences. - Moscow: Moscow State University, 2006. - 150 p.

11. Ramatov J. (co-authored) Armed Forces Guarantee of Stability / History, Present and Future of the Armed Forces of the Republic of Uzbekistan. Materials of the Republican scientific-practical conference. - Tashkent: MV, 2005. - P. 1720.

12. Raxmonov A.R. Security problems. - T., 2009.

13. Rahmonov A. Public administration in the Republic of Uzbekistan. - Tashkent: Academy, 2007, page 6.

14. Rashidov R.R. Influence of international and regional processes on the formation of Afghan statehood // Written dissertation for the degree of Doctor of Philosophy (PhD) in Political Science. Tashkent, 2018. - 47 p.

15. Samarov R. Mechanism of psychological security of information // Methodological manual. - Tashkent: University, 2015. - 96 p.
16. Samarov R. Armed forces are the guarantor of the country's security and stability in the region // History, present and future of the Armed Forces of the Republic of Uzbekistan. Materials of the Republican scientific-practical conference. - Toshkent: MV, 2005. - P. 226-229.

17. Torkunova O.I., Mashin V.N., Rakhmetov A.A. Military traditions of the officers of the Russian army as the basis of the spiritual and moral education of cadets of military universities // Spiritual and moral education of youth: traditions and innovations. Mater. int. scientific and practical conf. - Voronezh: Voronezh State University Publishing House, 2015. P. 154-157.

18. Explanatory dictionary of the Uzbek language: "National encyclopedia of Uzbekistan". - Tashkent: State Scientific Publishing House, 2006. - 89 p.

19. National Encyclopedia of Uzbekistan. 1 vol. - Tashkent: State Scientific Publishing House, 2000. - P.375. 